\title{
Social and ecological aspects of the water resources management of the transboundary rivers of Central Asia
}

\author{
PARVIZ NORMATOV \\ Tajik National University, 17 Rudaki Ave, Dushanbe, 734025, Tajikistan \\ umarova52@gmail.com
}

\begin{abstract}
The Zeravshan River is a transboundary river whose water is mainly used for irrigation of agricultural lands of the Republic of Uzbekistan. Sufficiently rich hydropower resources in upstream of the Zeravshan River characterize the Republic of Tajikistan. Continuous monitoring of water resources condition is necessary for planning the development of this area taking into account hydropower production and irrigation needs. Water quality of Zeravshan River is currently one of the main problems in the relationship between the Republics of Uzbekistan and Tajikistan, and it frequently triggers conflict situations between the two countries. In most cases, the problem of water quality of the Zeravshan River is related to river pollution by wastewater of the Anzob Mountain-concentrating Industrial Complex (AMCC) in Tajikistan. In this paper results of research of chemical and bacteriological composition of the Zeravshan River waters are presented. The minimum impact of AMCC on quality of water of the river was experimentally established.
\end{abstract}

Key words transboundary; Central Asia; water reservoir; pollution; heavy metals; water quality

\section{INTRODUCTION}

Water resources in the Aral Sea Basin, whose territory belongs to five states, are mostly used for irrigation and hydropower engineering. These water users require river runoff to be regulated with different regimes. The aim of the hydropower engineering is the largest power production and, accordingly, the utilization of the major portion of annual runoff of rivers in the winter, the coldest season of the year. Irrigation requires the largest water volume to be available in the summer, during the vegetation period.

River runoff regulation is exercised by large reservoirs, which, along with hydropower stations are operated as part of complex purpose hydroschemes.

The largest hydropower stations have been constructed in the republics of the runoff formation zone in the upper reaches of the Amudarya and Syrdarya rivers - in Kyrgyzstan and Tajikistan, while the major land areas to be irrigated are concentrated in the republics in the lower reaches of the rivers - Kazakhstan, Turkmenistan, and Uzbekistan. The problems of water resources use and the appropriate river runoff regulation were solved in the USSR by administrative command methods, based on nationwide interests. The interests of individual branches and republics were of secondary significance. The situation has radically changed after the collapse of the Soviet Union and the formation of five independent states in Central Asia.

The conflict of interests between hydropower engineering and irrigated farming has become evident and acquired transnational significance (Petrov and Normatov 2010).

Zeravshan River, with a length of $877 \mathrm{~km}$, has average discharges of about $162 \mathrm{~m} / \mathrm{s}$. It originates from Zeravshan glacier in the mountains between Turkestan and Zeravshansk. From the total water intake of Zeravshan River $(4834 \mathrm{mcm})$, only $253 \mathrm{mcm}(5.23 \%)$ come to the Republic of Tajikistan (Nurmakhmadov 2005).

The present article is devoted to monitoring of a condition and extent of degradation of glaciers, an assessment of hydroenergy resources of the Zeravshan River basin and the extent of influence of reservoirs on coastal agroclimatic parameters to a reservoir of agricultural areas. The ecologo-economic consequences of floods in mountain regions of the Zeravshan valleys are also studied.

\section{HYDROPOWER POTENTIAL OF THE ZERAVSHAN RIVER BASIN}

It is necessary to notice that for the Republic of Tajikistan the total hydropower potential of the Zeravshan River basin makes 11.8 billion $\mathrm{kWt} \cdot \mathrm{h}$ (Nurmakhmadov 2005). 
The mutual combination of interests of upstream and downstream countries of the Zeravshan River is quite achievable by building a cascade of hydropower stations (HPS), with regulation of the river drain.

It causes some discontent in Uzbekistan, connected with the realization of programs on development of a hydropower potential of the river by building a number of water reservoirs, that leads to deficiency of water in the vegetation period of agricultural crops.

The cardinal solution of the conflict situation between irrigation and water-power engineering is their joint development by building new HPS with reservoirs. For water-power engineering it means an increase in production of cheap and ecological pure energy and for irrigation, an increase of depth of long-term regulation of a drain and water security of already mastered lands, and possibility of new development. At present, of several HPS with reservoirs the top reservoir can work only in power mode, the bottom reservoir of the same volume can be regulated to drain to restoration of its natural regime. In particular, it can provide drain regulation in the interests of irrigation. At present, not two but with many HPS with reservoirs, the situation will improve even more (Petrov and Normatov 2010).

It is established (Normatov 2013) that during 1968-2000 the average annual temperature in three agricultural areas adjoining the Nurek reservoir increased by $1.0-1.5^{\circ} \mathrm{C}$ at the reduction of humidity to about $17 \%$ and the increase of evaporation to $12 \%$. For example, in the Yavan valley of the Republic of Tajikistan, recommended irrigation regimes are connected with the overexpenditure of water resources. Last specifications on irrigation modes to take the Yavan valley on mean annual value of humidity (0.35) to the category of drought areas. However, as shown in the data obtained, for the last 20 years evaporation in a valley has decreased to almost $300 \mathrm{~mm}(17 \%)$ and the amount of precipitation has risen to $70 \mathrm{~mm}(11 \%)$. As a result humidity has risen to 0.45 . Hence present irrigating norms for cultivation of cotton in the Yavan valley of $1100 \mathrm{~m}^{3} / \mathrm{ha}$ and $3000 \mathrm{~m}^{3} /$ ha for lucerne are overestimated. Calculations show that unproductive losses of water on only two valleys make more than $60 \mathrm{Mln} . \mathrm{m}^{3}$.

\section{WATER QUALITY OF THE ZERAVSHAN RIVER}

Water relations between Central Asia republics during the Soviet Union time were regulated by "Complex Use and Protection of Water Resources Schemes" in Amudarya and Syrdarya basins (Normatov and Petrov 2004).

The main purpose of working out basin "Schemes" was to define real volumes situated within the Amudarya and Syrdarya basins and that available for using water resources. It was also providing their fair allocation among region republics, meeting all the water users' interests. It should be noticed that a number of important aspects were not considered and included in "Schemes", for the situation has greatly changed since 1980 (year of the last "Schemes" specification and completion of hydraulic range composition). Mainly it concerns the ecologic requirements and sanitary waste thrown into rivers and channels. Overusing basin runoff in irrigational lands was planned as maximum use by the "Scheme" resulted in new problems appearing. They are:

(a) Deterioration of ecological condition, sometimes lead to ecological disasters in the river lowlands of the Aral Basin;

(b) High pollution of river water with pesticides, herbicides, other harmful elements and water mineralization increase.

The problem of studying the water quality change and development of mechanisms of its control is still concerned not only for the countries of Central Asia, but also for all the states in the region.

For stabilization of the ecological situation in the region, a large number of measures are offered. According to one measure it is necessary to limit water intake, with some changes allowing the water users downstream to intake the greater water volume in percentage terms. The adoption of this limited water intake system will allow regulation of water intake from the rivers, not only in view of irrigated lands, but also in view of water quality and its degree of mineralization. 
Nowadays, one of the most polluted rivers of Central Asia is Zeravshan River. The capacity of this water is changed under the influence of collector drainage water of irrigating basin zone and wastewater of Samarqand, Kattakurgan, Navoy and Bukhara cities. Mineralization of water increases from the origin to the estuary from $0.27-0.30 \mathrm{~g} / \mathrm{L}$ to $1.5-1.6 \mathrm{~g} / \mathrm{L}$ (Chembarisov 2001). Now after declaration of Tajikistan about the maximum use of hydropower potential of waterways of the Zeravshan River basin, the question of water quality of the river, although it existed for many years, again rise from Uzbekistan. Many consider a problem of water quality in organic communication with the activity of the Anzob mountain-metallurgical industrial complex (AMCC).

AMCC is a mining enterprise for extraction and enrichment of complex mercury-antimony ores of the Dzhizhikrut deposit of Tajikistan. In 2010 we did a complex of physical and chemical analyses for water quality of Zeravshan River. Results of analysis are presented in Table 1 and Figs 1-3.

Table 1 Physical-chemical analyses results of Zeravshan River waters.

\begin{tabular}{|c|c|c|c|c|c|c|c|c|c|c|c|}
\hline \multirow{2}{*}{$\begin{array}{l}\mathrm{T} \\
\left({ }^{\circ} \mathrm{C}\right)\end{array}$} & \multirow[t]{2}{*}{$\mathrm{pH}$} & \multirow[t]{2}{*}{$\chi(\mu \mathrm{S} / \mathrm{sm})$} & \multicolumn{9}{|c|}{$\mathrm{mg} / \mathrm{L}$} \\
\hline & & & $\mathrm{O}_{2}$ & $\mathrm{NO}_{3}$ & $\mathrm{NO}_{2}$ & $\mathrm{PO}_{4}$ & $\mathrm{NH}_{4}$ & $\mathrm{~Pb}$ & $\mathrm{Zn}$ & $\mathrm{Sb}$ & As \\
\hline 15.9 & 8.41 & 285 & $3-5$ & 0 & 0 & 50 & 0 & 0 & 0 & 0 & 0 \\
\hline 13.8 & 8.4 & 269 & 7 & 10 & 0 & 100 & 0 & 0 & 0 & 0 & 0 \\
\hline 16.2 & 8.4 & 280 & 5 & 10 & 0 & 100 & 0 & 0 & 0 & 0 & 0 \\
\hline 15.7 & 8.4 & 289 & $5-7$ & $0-10$ & 0 & 50 & 0 & 0 & 0 & 0 & 0 \\
\hline 14.2 & 8.4 & 244 & 7 & $0-10$ & 0 & 0 & 0 & 0 & 0 & 0 & 0 \\
\hline 13.3 & 8.5 & 250 & 7 & $5-10$ & 0 & 0 & 0 & 0 & 0 & 0 & 0 \\
\hline 13.3 & 8.4 & 247 & $5-7$ & 10 & 0 & 0 & 0 & 0 & 0 & 0 & 0 \\
\hline 12.3 & 8.5 & 250 & 5 & $0-10$ & 0 & 50 & 0 & 0 & 0 & 0 & 0 \\
\hline 16.1 & 8.3 & 243 & $1-3$ & $0-10$ & 0 & 250 & 0 & 0 & 0 & 0 & 0 \\
\hline 17.1 & 8.4 & 280 & 0 & $0-10$ & 0 & 100 & 0 & 0 & 0 & 0 & 0 \\
\hline 16.8 & 8.5 & 248 & 5 & $0-10$ & 0 & 100 & 0 & 0 & 0 & 0 & 0 \\
\hline 17.3 & 8.4 & 255 & 3 & 0 & 0 & $100-250$ & 0 & 0 & 0 & 0 & 0 \\
\hline
\end{tabular}

T. Temperature. $\chi$. Electroconductivity.

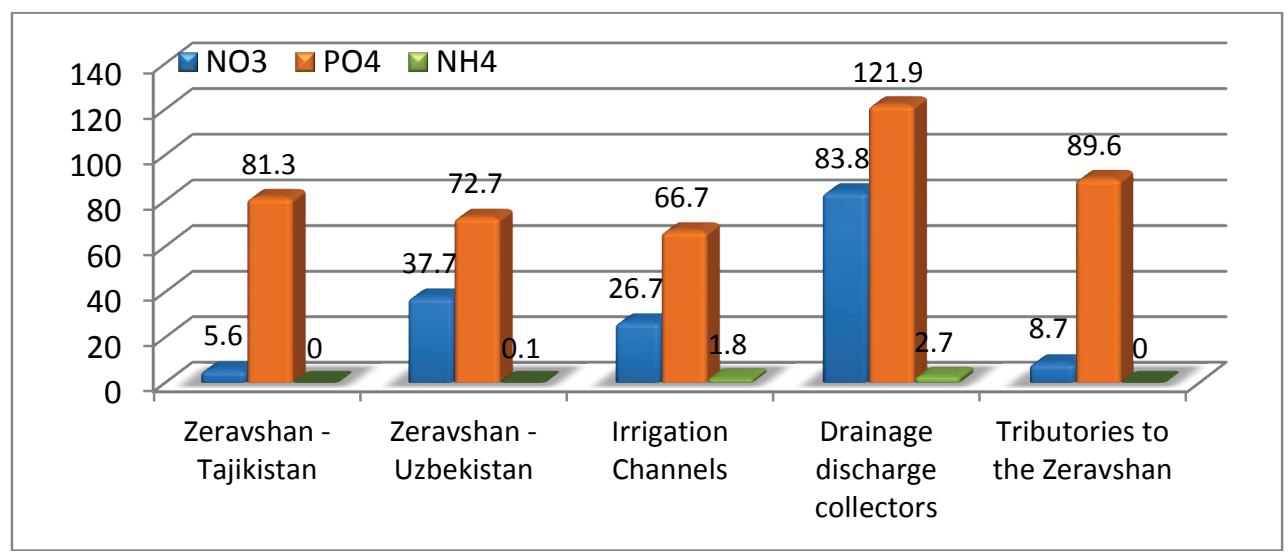

Fig. 1 Content of nitrate, phosphate and ammonium of Zeravshan River in Tajikistan and Uzbekistan territories, irrigation channels, drainage collectors in Uzbekistan and tributaries of Zeravshan River.

From Table 1 and Figs 1-3 it becomes evident that in waters of the Zeravshan River and its inflows the maintenance and excess of concentration of heavy metals of maximum permissible concentration are not observed. The influence of the combination on quality of water were defined by differences between indicators of chemical analyses of the waters sampling in points located before and after a place of mixing of river water with sewage.

The penetrating comprehension of water importance in the region and social responsibility for steady water supply needed, for example, the immediate reaction of five governments in Central Asia. In February 1992 the Interstate Coordination Water Commission (ICWC) was founded. The 


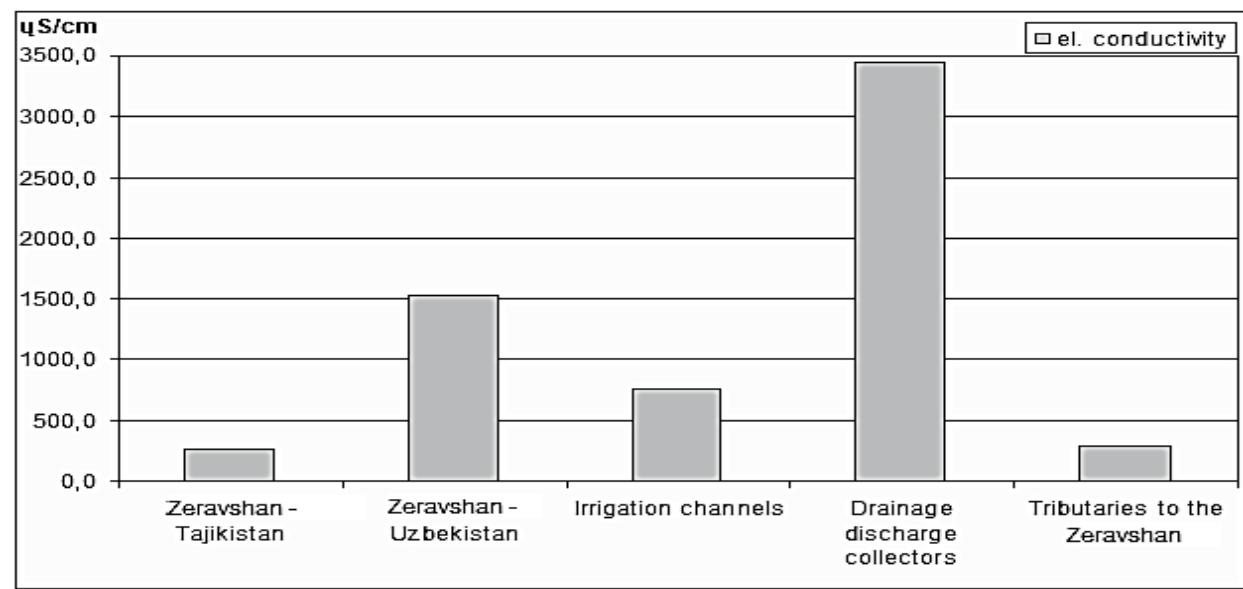

Fig. 2 Electrical conductivity of Zeravshan River in Tajikistan and Uzbekistan territories, irrigation channels and drainage collectors in Uzbekistan and tributaries of Zeravshan River.

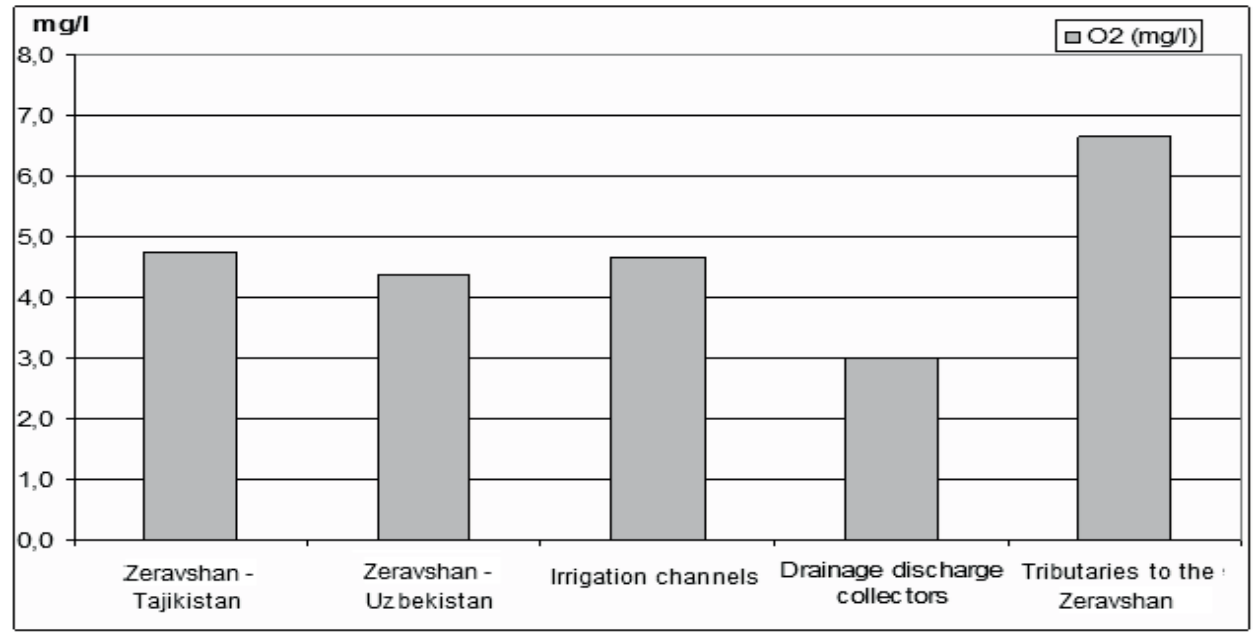

Fig. 3 Content of oxygen of Zeravshan River in Tajikistan and Uzbekistan territories, irrigation channels and drainage collectors in Uzbekistan and tributaries of Zeravshan River.

foundation of ICWC in difficult and unpredictable post-Soviet time enabled the countries of the region to painlessly pass the period of water "anarchy", to ensure equilibrium and consent in the region and has shown strategy of all countries to ensure mutual understanding and respect in fruitful cooperation today and in the future.

The problem of contamination and increase of mineralization degree of water arteries can be solved by creating (similar ICWC) Interstate Coordination Water Quality Commission (ICWQC). The structure of such organization is presented in Fig. 4.

The main function of the "interstate experts" is to compare the republican experts' information about water composition and to solve disputable questions by carrying out independent expert appraisals of water quality of Transboundary Rivers. The ICWQC Secretary appoints staff and sets the terms of interstate expert's power. In information centres that were established in each country of Central Asia, water quality control statistics in industrial, agricultural, municipal sectors and hydroposts are gathered, generalized and systematized. Thus, the data concerning water arteries quality from each country come to the Analytical Center of ICWQC. It should be noted that after reaching the complete transparency of relative composition and quality of all water arteries in Central Asia the next stage is the development of mechanisms to encourage and take measures to the states polluting water environment. These problems together with other questions should be studied at the ICWQC Secretariat for consideration at the Meeting of Central Asia. 


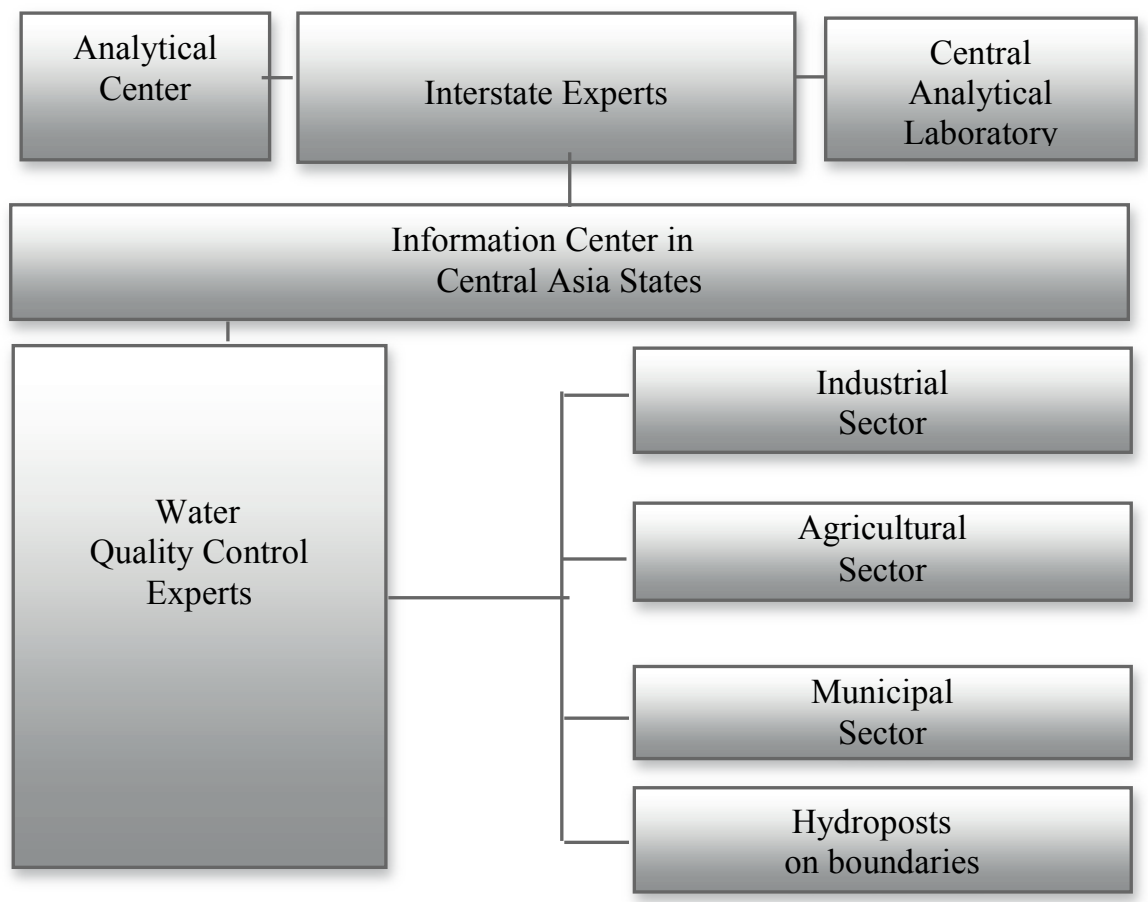

Fig. 4 Structure of the Interstate Coordination Water Quality Commission.

\section{CONCLUSIONS}

Results of comparison of the analysis of waters sampling in two points located up to and after the Anzob mountain concentrating industrial complexes (AMCIC) show the absence of essential pollution of waters of the Zeravshan River by wastewaters of AMCIC. Moreover, it changed under the influence of collector drainage water of irrigating basin zone and wastewater of Samarqand, Kattakurgan, Navoy and Bukhara cities of Uzbekistan. For a solution of the problem of pollution of the Transboundary Zeravshan River, the creation of the Interstate Coordination Water Commission (ICWC) for the Central Asian region is offered.

\section{REFERENCES}

Chembarisov, E .I. (2001) Modern hydrological problems of water resources of Central Asia and ways of their decision. Water and steady development. Bishkek. Publ. Center FPOI, 82.

Normatov, I. (2013) The impact of water reservoirs on biodiversity and food security and creation of adaptation mechanisms. Proc. AASSA Regional Workshop on Sustainable development of Asian countries, water resources and biodiversity under climate change, 19-22 August 2013, Barnaul, Russia.

Nurmakhmadov, D. (2005) Hydropower of Tajikistan: current state and development prospect. Abs. Int. Conf. Status, problems and prospects of development of banking system in Central Asian Republics in the stage of transition to market relationship, Dushanbe, Tajikistan, 21.

Petrov, G. and Normatov, I. (2010) Conflict of interests between water users in the Central Asian Region and possible ways to its elimination. Journal Water Resources 37, 113-120. 